\title{
Tenure and Promotion Experiences of Academic Librarians of Color
}

\section{Ione T. Damasco and Dracine Hodges}

This study broadly examines factors impacting work-life experiences of library faculty of color within the framework of tenure policies and processes. An online survey was sent out to academic librarians of color to gauge perceptions of tenure and promotion policies and processes, professional activities and productivity, organizational climate and culture, and job satisfaction and retention. Results of the survey showed mixed findings regarding the impact of race on the tenure and promotion process. Findings can be used to inform future discussions of recruitment and retention for academic librarians of color and to improve the overall tenure experience.

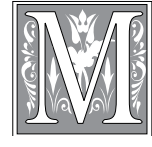

any institutions of higher education have seen steady increases in the racial and ethnic diversity of their student populations over the last few decades. However, this trend has not been reflected in the demographics of the faculty who work at these institutions. Faculty of color often find themselves one of a very small number of racial or ethnic minorities in their departments. In some cases, the faculty member is the only person in a department who identifies with a traditionally underrepresented group, such as African Americans, Asian Americans, Latinos, or Native Americans. Like most faculty, their work-lives are governed explicitly by the tenure process, a rigorous process involving high standards of performance expectations in the areas of scholarship, service, and teaching that can be challenging for any faculty member.
However, these challenges are further complicated by implicit barriers and issues that racial and ethnic minorities often face when working in predominantly White environments. Academic librarians of color who are trying to earn tenure may face many of the same pressures, expectations, and challenges as their teaching faculty of color counterparts. Both the field of higher education and the field of librarianship have emphasized the importance of increasing the racial and ethnic diversity of their respective workforces. However, increased recruitment of faculty of color does not guarantee increased retention rates.

The purpose of this study is to examine the work-life experiences of librarians of color who are currently seeking tenure and/or promotion or who have undergone the tenure and/or promotion process. The focus of much of the literature

Ione T. Damasco is Cataloger Librarian in the Roesch Library at the University of Dayton; e-mail: ione. damasco@notes.udayton.edu. Dracine Hodges is Head, Acquisitions Department at The Ohio State University Libraries; e-mail: hodges.368@osu.edu. (C) 2012 Ione T. Damasco and Dracine Hodges, AttributionNonCommercial (http://creativecommons.org/licenses/by-nc-sa/3.0/) CC BY-NC 
in librarianship related to diversity has been on recruitment, but a parallel issue is that of retention, and research on the retention of academic librarians of color is practically nonexistent. Although much research has been conducted on the experiences of teaching faculty of color, issues facing library faculty of color may differ. This research gap has led the authors to ask the following questions:

- What are the obstacles to earning tenure and/or promotion from the standpoint of librarians of color?

- What initiatives, resources, programs, and so on are in place to ensure tenure-track librarians of color successfully achieve tenure and/or promotion?

- What is the relationship, if any, between the tenure and/or promotion process and the retention of academic librarians of color?

\section{Literature Review}

The recruitment and retention of members of traditionally underrepresented groups in the field of librarianship has been an issue of concern in the profession for decades, dating back to the 1920s, when the American Library Association (ALA) first supported the library training and education of African Americans. ${ }^{1}$ Despite ALA's continued efforts to recruit and retain racial and ethnic minority librarians, recent statistics indicate a persistent disparity in the numbers of degreed librarians who identify as members of one or more underrepresented groups. The 2007 report Diversity Counts, issued by ALA, provides a demographic overview of the changing library landscape between the years 1990 and $2000 .{ }^{2}$ According to the report, the total number of degreed African American and Latino librarians under the age of 45 decreased between 1990 and 2000 despite recruitment efforts. In terms of the academic library landscape, White women and men continued to constitute a significant majority. Academic libraries saw a decrease in the numbers of African American and
Latino academic librarians between 1990 and 2000. As of 2000, White librarians accounted for 85 percent of the total number of degreed librarians working in academic libraries. That number remained fairly stable, with only a 2.3 percent decrease between 1990 and 2000, compared to a 13.6 percent decrease in the number of African American academic librarians and a 44.7 percent decrease in Latino academic librarians for the same period. Although the report indicates a positive percentage increase in the numbers of Asian/Pacific Islander and Native American librarians working in academic libraries during that period (17.2\% and $309.4 \%$, respectively), serious questions about continued overall demographic underrepresentation in the field of academic librarianship persist. Recruitment efforts may have increased over the last twenty years, but retention efforts have clearly not been as successful, particularly for African American and Latino academic librarians.

The ALA report does not indicate what percentage of academic librarians, regardless of race or ethnicity, hold faculty status at their institutions. Although there has been much debate over the years regarding the issue of faculty status for academic librarians, concrete numbers of academic librarians working under the auspices of faculty status, with all of its related rights and responsibilities as outlined by the Association for College and Research Libraries, is not readily available. ${ }^{3}$ Previous research on faculty status and academic librarianship has tended to focus on tenure and promotion policies and practices. ${ }^{4}$ Library faculty are often evaluated for promotion and tenure in similar categories to traditional teaching faculty, namely research, service, and job performance. In some cases, faculty librarians are governed by tenure and promotion policies that are identical to teaching faculty, who are normally evaluated in the categories of teaching, research, and service.

Despite the fact that some institutions have programs in place to assist new li- 
brary faculty as they start down a career path toward tenure and promotion, most academic libraries neglect to measure retention of librarians, especially librarians of color, against any sort of benchmark. ${ }^{5}$ Plenty of advice exists in the literature for library faculty regarding ways to successfully navigate the waters of tenure and promotion. ${ }^{6}$ New library faculty are advised to be organized, to seek out peer mentors, to develop a balanced and regularly updated portfolio, to set realistic expectations, to avoid too many service commitments, and to recognize job stressors in order to seek help when needed. In an attempt to mitigate some of the challenges faced by new faculty librarians, some institutions have developed programs to assist them. Some of these programs are for all library faculty, regardless of race or ethnicity. ${ }^{7}$ These programs highlight mentoring and peer support as valuable tools to help new librarians succeed. However, there are also programs geared specifically toward librarians of color. The Minnesota Institute for Early Career Librarians from Traditionally Underrepresented Groups (MIECL) is designed for new librarians of color and held at the University of Minnesota on a biennial basis. It serves as an example of how group mentoring, networking, and professional development can function as ways to ensure successful retention. ${ }^{8}$ Another program held at Colorado State University, "The New Beginnings Program," brings senior library faculty of color together with junior library faculty of color to help socialize them into the academic workplace. ${ }^{9}$ This program offers junior faculty the opportunity to seek out research advice, develop grant-writing skills, and gain a better understanding of the faculty evaluation process.

Job satisfaction studies of librarians of color have also been conducted in libraries as a means of exploring possible factors in retention. ${ }^{10}$ One study of African American academic librarians at Association of Research Libraries (ARL) institutions identified several factors re- lated to job satisfaction. These included feelings of isolation, adequacy of library diversity programs, working conditions, support from peers, and variations in standards of performance. ${ }^{11}$ To date, not enough research has been conducted on job satisfaction and faculty librarians of color to determine if there is a strong correlation with retention.

One aspect of academic librarianship that has been examined extensively in the literature is scholarly activity. Conducting research and writing for publication are often the most challenging aspects of working toward tenure. Several studies have examined the research productivity of academic librarians, normally measured by the number and type of publications academic librarians produce. ${ }^{12}$ The age-old adage to "publish or perish" may seem daunting for academic librarians, and there has been some debate over what are considered appropriate levels for scholarly output. ${ }^{13}$ A case study at Pennsylvania State University, where librarians are among the most productive in the nation in terms of scholarly publications, defined specific factors that facilitated such high productivity levels. ${ }^{14}$ These factors include previous formal research training, collegial support through formal and informal mentoring, and the overall collegial climate-funding availability for research travel, individually negotiated release time for research, and the sense that all research agendas are valued. Another case study at Oregon State University highlighted the presence of a formal faculty association designed to foster research and scholarly activities, composed of both untenured and tenured librarians. ${ }^{15}$ This association provides opportunities for librarians to obtain feedback on their research and to identify new research collaborations and possibilities. However, neither study specifically disaggregates their results by race or ethnicity, so it is difficult to obtain a snapshot of the overall research productivity of library faculty of color. Since research is a heavily weighted component of tenure 
and promotion evaluations, examining the scholarly output of library faculty of color is essential.

Understanding the academic landscape for teaching faculty can provide greater insight into issues facing library faculty. Research on teaching faculty retention in higher education has tended to focus on the faculty as a whole, without disaggregating by race or ethnicity. Despite the fact that student populations of universities and colleges have become more diverse, colleges and universities continue to struggle with the recruitment, representation, and overall retention of faculty of color. Emerging research has begun to explore the experiences of faculty of color, particularly in terms of determining factors related to retention.

Studies of job satisfaction for teaching faculty of color have highlighted some of the issues they face in academia. ${ }^{16}$ Often, faculty of color find themselves as a minority presence in their departments or their institutions and, as such, face a variety of issues that their White counterparts may not experience. Recurrent themes have appeared in numerous studies of women faculty and faculty of color: feelings of isolation and tokenism; lack of access to social networks; lack of mentors; perceptions that their research is undervalued; challenges in terms of negotiating identity; hidden workloads; lack of support; differing expectations; and organizational climate issues. ${ }^{17} \mathrm{Un}$ derstanding the academic workplace, often described as "chilly" for women faculty and faculty of color, is essential to understanding how these and other barriers to inclusion persist and how they can negatively impact retention. ${ }^{18}$

Working within the framework of critical race theory (CRT), which "challenges the experiences of Whites as the normative standard and grounds its conceptual framework in the distinctive experiences of people of color, ${ }^{19}$ Christine A. Stanley conducted an autoethnographic, qualitative study of the first-hand experiences of faculty of color. ${ }^{20}$ These faculty members used narrative to explore their experiences in predominantly White institutions. Several significant themes emerged from these narratives that speak to a commonality of experience for faculty of color. Respondents spoke at great length about their experiences with teaching, mentoring, collegiality, identity, service, and racism. Their narratives reiterated the findings of previous studies of underrepresented faculty. Through the lens of CRT, this particular study provided the opportunity for an in-depth qualitative analysis of the experiences of faculty of color that placed them at the center of the research, rather than in relation to the experiences of White faculty.

When the findings in existing literature are synthesized, a complex picture of the worklife of faculty of color emerges. Faculty of color more frequently find themselves burdened with teaching loads and service responsibilities that may detract from their research activity, research that may already be undervalued by their colleagues. They are usually expected to assume institutional roles (such as that of the "diversity specialist") that are often ignored in terms of tenure and promotion evaluations. Faculty of color may struggle with negotiating their sense of identity within the culture of their department or institution to ensure a good "organizational fit." Finding ways to become fully socialized into the culture of their department may be particularly difficult if they lack good mentors, which in turn can lead to missed opportunities and resources in terms of research and service. All of these issues, combined with the possibility of working in a racially insensitive or hostile climate, can function as job stressors that may ultimately lead faculty of color to leave their institutions, either of their own volition or because they fail to meet the requirements to achieve tenure or promotion. Library faculty of color may face the same issues. However, no comprehensive qualitative studies have been conducted to determine if these issues hold true for library faculty of color. 


\section{Methodology}

An online six-part survey consisting of 45 closed and open-ended questions was created and distributed to various e-mail lists. The survey was targeted specifically at academic librarians of color who hold a terminal degree in librarianship, hold faculty status at their institutions, and are either on the tenure track or have already earned tenure. For the purposes of this study, the phrase "academic librarians of color" refers to all non-White librarians who work in an academic library. To ensure broad participation, the survey was sent out to numerous e-mail lists, including those hosted by professional associations based in the United States that specifically serve librarians of color. Respondents were also asked to forward the survey e-mail to other appropriate lists. The survey was open for a period of six weeks, from November 3, 2009, to December 15, 2009.

\section{Limitations}

Statistical information about numbers of racially or ethnically underrepresented academic librarians holding faculty status and working either as tenure-track or tenured librarians was not readily available when the survey was conducted. Since it was not possible to determine the total population size of potential respondents, the survey was distributed widely in an attempt to reach as many appropriate respondents as possible; therefore, typical sampling techniques were not used. Determining the geographic distribution of the survey respondents was another limitation of the survey, since it was distributed online. However, based upon the geographic origins of the sponsoring organizations for the e-mail lists through which the survey was initially disseminated, the researchers have assumed the responses have come from academic librarians working in the United States. Although the criteria for participation was stated in the introductory e-mail that accompanied each survey, the researchers anticipated that some responses would not be usable, due to possible misinterpretation of the criteria by respondents. Ninety-one surveys were returned. Incomplete, empty, and invalid surveys (such as responses from individuals who identified as nonfaculty, only White, and/ or were not governed by any kind of tenure and promotion policy) were filtered out. Ultimately, sixty valid surveys were analyzed.

\section{Demographics}

Demographic information about the respondents can be found in table 1 . A majority of the respondents (41.7\%) identified as Black or African American. Native Americans/Alaska Natives and Hawaiians or other Pacific Islanders made up the smallest groups of respondents, each group representing only 1.7 percent. A majority of the respondents $(76.7 \%)$ were female. One-third of the respondents fell between the ages of forty-five and fifty-four, followed closely by those who fell between the ages of thirty-five and forty-four (26.7\%). A majority of the respondents also stated they had extensive professional experience; 55 percent of the respondents indicated they had worked for nine or more years as a degreed librarian. Many respondents held additional degrees; 50 percent held a second master's degree, and an additional 6.7 percent held an additional doctorate or equivalent degree. No single discipline was prevalent among the responses; a wide range of degrees was listed, including degrees in the humanities, law, social sciences, and the sciences.

Occupational characteristics, such as institution type, contract type, faculty rank, and faculty status are summarized in table 2 . The largest group of respondents $(40.0 \%)$ was employed at doctorate-granting institutions. A significant majority of the respondents $(75.0 \%)$ indicated they worked with a twelvemonth annual contract. A handful of respondents provided other models, such as nine-month contracts. The prevalence of twelve-month contracts has implica- 


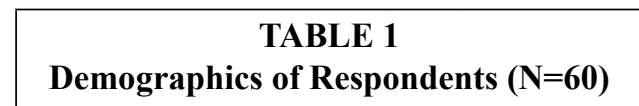

\begin{tabular}{|c|c|c|}
\hline Characteristic & $n$ & $\begin{array}{c}\text { Percentage } \\
\text { of Total } \\
\text { Responses }\end{array}$ \\
\hline \multicolumn{3}{|l|}{ Race or Ethnicity } \\
\hline $\begin{array}{l}\text { American Indian/Alaska } \\
\text { Native }\end{array}$ & 1 & $1.7 \%$ \\
\hline Asian & 13 & $21.7 \%$ \\
\hline Black or African-American & 25 & $41.7 \%$ \\
\hline Hispanic or Latino & 10 & $16.7 \%$ \\
\hline $\begin{array}{l}\text { Native Hawaiian or other } \\
\text { Pacific Islander }\end{array}$ & 1 & $1.7 \%$ \\
\hline Multiracial/multiethnic & 10 & $16.7 \%$ \\
\hline \multicolumn{3}{|l|}{ Gender } \\
\hline Female & 46 & $76.7 \%$ \\
\hline Male & 13 & $21.7 \%$ \\
\hline No response & 1 & $1.7 \%$ \\
\hline \multicolumn{3}{|l|}{ Age } \\
\hline Under 35 years old & 12 & $20.0 \%$ \\
\hline $35-44$ years old & 16 & $26.7 \%$ \\
\hline $45-54$ years old & 20 & $33.3 \%$ \\
\hline $55-64$ years old & 12 & $20.0 \%$ \\
\hline Over 65 years old & 0 & $0.0 \%$ \\
\hline \multicolumn{3}{|l|}{ Education Level } \\
\hline MLS or MLIS only & 26 & $43.3 \%$ \\
\hline $\begin{array}{l}\text { Additional master's degree } \\
\text { or equivalent }\end{array}$ & 30 & $50.0 \%$ \\
\hline $\begin{array}{l}\text { Additional doctoral degree } \\
\text { or equivalent }\end{array}$ & 4 & $6.7 \%$ \\
\hline \multicolumn{3}{|l|}{$\begin{array}{l}\text { Number of Years Worked } \\
\text { as a Degreed Librarian }\end{array}$} \\
\hline Less than a year & 1 & $1.7 \%$ \\
\hline $1-3$ years & 7 & $11.7 \%$ \\
\hline $3-5$ years & 5 & $8.3 \%$ \\
\hline $5-7$ years & 9 & $15.0 \%$ \\
\hline $7-9$ years & 5 & $8.3 \%$ \\
\hline More than 9 years & 33 & $55.0 \%$ \\
\hline
\end{tabular}

tions for tenure achievement, such as time for research. Teaching faculty who work under the traditional ninemonth contract often conduct the bulk of their research and writing during the three months when they are not required to fulfill classroom teaching obligations. Library faculty who work year-round may encounter critical time-management issues when faced with the prospect of juggling daily work tasks with research and writing activities.

Respondents indicated years of service with their current institutions, as well as their faculty rank and position status. Many respondents had been at their institution for a significant period of time; 25 percent had worked at their current workplace for more than nine years, while an additional 15 percent had worked between seven and nine years at the same library. Depending upon the institution's policies, tenure is usually awarded at the beginning of the sixth or seventh year of a faculty member's employment. Twenty-four respondents indicated they had already achieved tenure. Most of the respondents $(58.0 \%)$ indicated they were currently on the tenure track. Only one respondent stated s/he had been recently denied tenure and was seeking employment elsewhere. The majority of respondents stated they were ranked as assistant professors. Some variation in the wording of faculty rank did occur -15 percent of the respondents listed other titles, such as "Assistant Librarian," "Associate Librarian," "Librarian (full)," "Librarian II," or "Librarian III." A clear delineation between teaching faculty and library faculty is implicit in the use of such titles. These markers of difference may be illusory, however, if library faculty face the same expectations as teaching faculty for the attainment of tenure.

Job responsibilities varied greatly among respondents. Reference was 


\begin{tabular}{|c|c|c|}
\hline \multicolumn{3}{|c|}{$\begin{array}{c}\text { TABLE } 2 \\
\text { Occupational Characteristics of } \\
\text { Respondents }(\mathrm{N}=60)\end{array}$} \\
\hline Characteristic & $n$ & $\begin{array}{c}\text { Percentage } \\
\text { of Total } \\
\text { Responses } \\
\end{array}$ \\
\hline \multicolumn{3}{|l|}{ Current Institutional Type $^{\mathrm{a}}$} \\
\hline Associate's college & 13 & $21.7 \%$ \\
\hline Baccalaureate college & 8 & $13.3 \%$ \\
\hline Master's college or university & 15 & $25.0 \%$ \\
\hline Doctorate-granting university & 24 & $40.0 \%$ \\
\hline \multicolumn{3}{|l|}{ Length of Annual Contract } \\
\hline 9 months & 2 & $3.3 \%$ \\
\hline 12 months & 45 & $75.0 \%$ \\
\hline Not applicable & 7 & $11.7 \%$ \\
\hline Other & 6 & $10.0 \%$ \\
\hline \multicolumn{3}{|l|}{ Current Position Status } \\
\hline Faculty with tenure & 10 & $16.7 \%$ \\
\hline $\begin{array}{l}\text { Faculty with tenure and still } \\
\text { eligible for promotion }\end{array}$ & 14 & $23.3 \%$ \\
\hline $\begin{array}{l}\text { Faculty, eligible for promotion } \\
\text { and on the tenure track }\end{array}$ & 35 & $58.3 \%$ \\
\hline Other & 1 & $1.7 \%$ \\
\hline \multicolumn{3}{|l|}{ Current Faculty Rank } \\
\hline Instructor/lecturer & 3 & $5.0 \%$ \\
\hline Assistant professor & 29 & $48.3 \%$ \\
\hline Associate professor & 15 & $25.0 \%$ \\
\hline Professor & 1 & $1.7 \%$ \\
\hline Not applicable & 3 & $5.0 \%$ \\
\hline Other (please specify) & 9 & $15.0 \%$ \\
\hline \multicolumn{3}{|c|}{ Number of Years at Present Institution } \\
\hline Less than a year & 4 & $6.7 \%$ \\
\hline $1-3$ years & 13 & $21.7 \%$ \\
\hline $3-5$ years & 8 & $13.3 \%$ \\
\hline $5-7$ years & 11 & $18.3 \%$ \\
\hline $7-9$ years & 9 & $15.0 \%$ \\
\hline More than 9 years & 15 & $25.0 \%$ \\
\hline \multicolumn{3}{|c|}{$\begin{array}{l}\text { aDefined according to Carnegie Basic Classification } \\
\text { scheme. Carnegie Foundation for the Advancement of } \\
\text { Teaching, "The Carnegie Classification of Institutions of } \\
\text { Higher Education," available online at http://classifica- } \\
\text { tions.carnegiefoundation.org/ [accessed } 1 \text { October 2009]. }\end{array}$} \\
\hline
\end{tabular}

the task cited most often both as a primary responsibility and as an additional work responsibility. Seventeen respondents indicated "other" as both their primary and additional work responsibilities and chose to list their specific tasks, sometimes enumerating multiple tasks that carried equal weight in terms of priority. A common combination of responsibilities included reference, instruction, and collection development. Almost all of the respondents indicated they had a variety of tasks to perform as part of their daily work.

\section{Tenure and Promotion Policies and Processes}

Before newly hired library faculty of color can plan their strategies for achieving tenure or promotion, they must have a clear understanding of their institution's specific tenure and promotion policies. Faculty librarians should be well informed from the time of hire about the expectations, criteria, and measures that will be used to evaluate them as they move through the process. Although a considerable majority of respondents $(79.7 \%)$ said they were provided with copies of tenure and promotion policies at the time of hire, a surprising number of respondents $(20.3 \%)$ were not given copies at the time of hire. Lack of early access to policies could hinder a librarian's ability to develop a plan for meeting tenure expectations in a timely manner.

Evaluation criteria for teaching faculty are typically defined as teaching, research or scholarship, and service. Library faculty may be evaluated similarly, although the criterion of teaching is sometimes replaced by job 
performance. As shown previously, typical job responsibilities of library faculty can encompass a broad range of activities rather than a single task like teaching. For example, librarians who teach regular bibliographic instruction sessions usually have other responsibilities as well, such as regular reference desk hours. Furthermore, such sessions often differ from other courses because they are rarely taught as credit-based courses that run for the entire length of an academic term. Teaching faculty are also assigned a specific course load for each academic term, whereas librarians engaged in instruction rarely have a set course load. They often provide instruction for many different disciplines over the course of the academic term. Given these differences, one might expect some variance between the tenure policies that govern library faculty and teaching faculty at the same institution, but this is not always the case.

Respondents identified the criteria by which they were evaluated for promotion and tenure. Job performance was cited most frequently, indicated by 91.7 percent of the respondents. Service was cited by 86.7 percent of the respondents, closely followed by research and publication, which was cited by 83.3 percent of the respondents. Half of the respondents stated teaching (regular, credit-based course instruction) was also a basis for evaluation. Other criteria included professional development activities, outreach, and bibliographic instruction evaluations. Two respondents stated they did not know what criteria were being used to evaluate faculty librarians for promotion and tenure.

To work successfully toward tenure or promotion, library faculty must have a clear understanding of their institution's procedures and performance expectations. According to 68.3 percent of respondents, the process for earning tenure and promotion was clearly defined. The actual criteria used for evaluation during that process were clearly defined according to 65 percent of the respondents. However, performance expectations were clear to only 56.7 percent of the respondents; 31.3 percent felt standards of performance were not clearly defined by their policies. Feedback from senior colleagues who have already undergone the process can help clarify policies that might be confusing, vague, or complex. Half of the respondents stated they received mixed messages from senior colleagues about the requirements for earning tenure and promotion. In terms of formal feedback from senior colleagues, 53.3 percent of respondents felt they had received constructive comments from colleagues, while 33.3 percent felt they had not. Respondents were also asked about informal feedback from their colleagues; 56.6 percent of respondents felt they had received constructive feedback on an informal basis, while 28.4 percent stated they had not. Despite these mixed results, a significant majority of the respondents $(81.7 \%)$ felt they understood what it would take to achieve tenure or promotion at their institution. These results imply library faculty of color use a variety of cues and sources to inform their understanding of tenure and promotion policies; reliance upon either strict documentation only or just the advice of others seems to be insufficient.

Respondents were invited to provide additional commentary about tenure and promotion policies at their institutions. Responses were a mix of positive and negative assessments. As stated before, some librarians are governed by the same policies that govern teaching faculty. One respondent remarked, "The processes and policies for faculty in general are well defined and articulated clearly in our contract-but they do not easily apply to librarians." Performing regular library work in addition to fulfilling expectations for tenure poses significant time management challenges for academic librarians. Another respondent echoed this sentiment:

There has always been a historical conflict between whether or not librarians are supposed to meet "traditional" faculty requirements 
(i.e. standards regarding teaching and/or scholarship and/or service) or "different" ones given our differences (i.e. we still need to perform library duties; 12 month contracts; standardized work week)... The standards of review are coming under increasing tension and scrutiny as it applies to the library faculty, because if we move towards being reviewed under "faculty" standards - then we need time to publish, and it minimizes the already restricted amount of time we have to "run the library." If we are pushed to be "librarians," then it restricts the time to do scholarship.

Several other respondents spoke about the increasing emphasis on research and scholarship as criteria for tenure and the difficulties of finding time to accomplish research tasks. As some respondents pointed out, inconsistencies exist at some institutions where policies are set at the department level, which can lead to very different expectations for faculty across a single institution. Others spoke about the challenges of trying to earn tenure at institutions where administrators are not convinced librarians should hold faculty status.

Several respondents gave more detailed commentary on feedback received from senior faculty members. They spoke favorably of both formal and informal mentoring processes that paired them with experienced, senior colleagues who guided them through the tenure process. One respondent mentioned the benefits of informal feedback: "I was lucky in that a senior individual (also a minority) here helped me enormously; otherwise, I would have been unaware of what I should have done to gain tenure." Individual personalities can have a significant impact upon a librarian's journey through the tenure process. Some respondents brought up the difficulties of discerning performance expectations when turnover rates were high for their supervisors. Another respondent wrote about the differences in feedback from senior colleagues: "Senior faculty tend to give different advice to my colleagues that I do not receive; either suggestions for service or publishing tips while I receive more offers to collaborate or participate on campus wide committees. While I am in a tenure-track position, I often feel that advice is definitely different depending on [senior] faculty perception of how much 'help' is needed."

A couple of respondents addressed the inconsistencies of the application of policies within a framework of racial discrimination. They wrote about perceived flaws in policy construction as well as perceived lack of support from colleagues. As one stated, "The policies and processes are deliberately vague, open to wide interpretation, and are not monitored to ensure consistent application. This makes it easy for racial discrimination to go on without the Library getting caught ... Feedback I receive is most often not constructive but antagonistic and often contains racist overtones. Overall the Library's practices, policies and processes around tenure and promotion exemplify institutionalized racism." While these sentiments were not expressed by the majority of respondents, these comments provide valuable insight into the potential pitfalls of poorly written and poorly implemented policies that could inadvertently lead to systems of inequity.

\section{Professional Activities and Productivity}

In addition to job performance, research and service are common evaluation criteria outlined in tenure and promotion policies; of these, research is often weighted more heavily. Respondents were asked to provide information regarding their research output and service activities.

\section{Research and Publication}

Publication is one of the most common measures used to evaluate faculty scholarship. While the number and types of 
publications required are rarely codified in tenure and promotion policies, visible scholarly output is essential for faculty members to succeed. Although facilitating research is arguably the foundation of librarianship, there is a belief by some that "librarians tend to lack the education and the opportunities to perform research that would be acceptable to institutional tenure committees." ${ }^{21}$ Such concerns may be warranted, especially when looking at the scholarly output of newer librarians; one researcher expressed concern over the "low productivity of librarians with five or fewer years of professional experience." 22 To obtain a broad snapshot of the research productivity of library faculty of color, the survey asked respondents about the types of research and writing activities in which they were engaged and how much time they spent on such tasks.

Writing for publication is a common way for many library faculty to satisfy the research component of tenure and promotion evaluations. Papers published in conference proceedings, articles appearing in peer-reviewed journals, and chapters contributed to books are all standard forms of scholarly publication. The survey asked respondents to indicate the number of acceptances they had received for different types of scholarly work they produced. A summary of this output can be found in table 3 . While a significant number of respondents (31.7\%) indicated they had not had any papers, articles, or chapters accepted for publication, as the table shows, a higher percentage of respondents had been successful in getting their work accepted for publication. Table 3 also shows acceptance data for conference presentation and poster session proposals. Conference presentations and poster sessions are often considered scholarly activities in terms of tenure expectations, especially when they serve as stepping stones toward publication. As with written publications, a majority of the respondents had their proposals accepted; only 26.7 percent of respondents had no presentation or poster proposals accepted.

Some institutions evaluate grant proposals as a form of scholarly activity, especially when the results of a successfully funded grant are published as an article. Respondents were asked to indicate the number of grant proposals they had submitted, as well as the number of proposals that were actually approved for funding, which can be found in table 4. Although more than half of the respondents had submitted grant proposals, most of those respondents had only submitted one to three proposals while in their current positions. Actual acceptance rates for grant proposals were considerably lower, with only 35 percent of the respondents receiving funding for their grant proposals. Effective grant-writing requires a great deal of skill, so novice grant writers often turn to other resources such as grant-writing workshops or grant specialists on their

\begin{tabular}{|l|c|c|}
\hline \multicolumn{3}{|c|}{ TABLE 3 } \\
\hline & \multicolumn{2}{|c|}{ No. (\%) of Respondents by Type of Submission } \\
\hline No. of Acceptances & $\begin{array}{c}\text { Papers, Journal Articles, } \\
\text { Book Chapters }\end{array}$ & $\begin{array}{c}\text { Conference Presentation and } \\
\text { Poster Session Proposals }\end{array}$ \\
\hline None & $19(31.7)$ & $16(26.7)$ \\
\hline $1-3$ & $22(36.7)$ & $27(45.0)$ \\
\hline $4-6$ & $9(15.0)$ & $8(13.3)$ \\
\hline $7-9$ & $3(5.0)$ & $3(5.0)$ \\
\hline More than nine & $7(11.7)$ & $5(8.3)$ \\
\hline No response & $0(0.0)$ & $1(1.7)$ \\
\hline
\end{tabular}




\begin{tabular}{|l|c|c|}
\hline \multicolumn{3}{|c|}{ TABLE 4 } \\
Grant Proposal Output (N=60) \\
\hline No. of Grant Proposals & $\begin{array}{c}\text { No. (\%) of Respondents } \\
\text { Who Submitted Proposals }\end{array}$ & $\begin{array}{c}\text { No. (\%) of Respondents Who } \\
\text { Had Proposals Funded }\end{array}$ \\
\hline None & $26(43.3)$ & $38(63.3)$ \\
\hline $1-3$ & $24(40.0)$ & $15(25.0)$ \\
\hline $4-6$ & $7(11.7)$ & $5(8.3)$ \\
\hline $7-9$ & $1(1.7)$ & $0(0.0)$ \\
\hline More than nine & $1(1.7)$ & $1(1.7)$ \\
\hline No response & $1(1.7)$ & $1(1.7)$ \\
\hline
\end{tabular}

campuses to assist them with the process. The dearth of successful grants being written by library faculty of color might be partially explained by a lack of grantwriting support. When asked, only 26.7 percent of the respondents stated they had adequate professional assistance in obtaining externally funded grants.

Library faculty conducting research and writing activities have needs that must be met to ensure productivity and success. Time is one of those precious commodities that librarians often find in short supply. Some institutions grant release time for faculty to engage in research activities; some may allow faculty to incorporate research into their daily routine. In either case, librarians may find it difficult to take advantage of that time allotment when trying to manage their daily workload. Most librarians spend a combination of scheduled work hours and personal time to accomplish research and writing goals.
Respondents were asked to indicate how much time per week they spent on research activities. Table 5 shows time spent on research activities during scheduled work hours and during respondents' personal time, outside of work. The largest group of respondents $(36.7 \%)$ spent between one and two hours a week at work on research. Thirty percent did not spend any time during normal work hours on research activities. As expected, respondents spent a considerable amount of personal time on research activities; on a weekly average, 25 percent spent between one and two hours on research, and 30 percent spent between three and four hours weekly of personal time on research tasks. Given the amount of personal time spent on research, it comes as no surprise that nearly half of the respondents later stated they did not have adequate release time to pursue research activities.

\begin{tabular}{|l|c|c|}
\hline \multicolumn{3}{|c|}{ TABLE 5 } \\
\hline & No. (\%) of Respondents Performing Research Activities \\
\hline No. of Hours Per Week & $\begin{array}{c}\text { During Scheduled Work } \\
\text { Time }\end{array}$ & $\begin{array}{c}\text { Outside of Scheduled } \\
\text { Work Time }\end{array}$ \\
\hline None & $18(30.0)$ & $12(20.0)$ \\
\hline $1-2$ & $22(36.7)$ & $15(25.0)$ \\
\hline $3-4$ & $11(18.3)$ & $18(30.0)$ \\
\hline $5-6$ & $4(6.7)$ & $6(10.0)$ \\
\hline More than six & $3(5.0)$ & $7(11.7)$ \\
\hline No response & $2(3.3)$ & $2(3.3)$ \\
\hline
\end{tabular}


Library faculty are evaluated ultimately according to their scholarly output. The survey asked respondents to provide a self-assessment of their research productivity levels in relation to the productivity of their colleagues. Just over half of the respondents (51.7\%) believed their productivity to be similar to their library faculty colleagues. Twenty percent felt they were less productive, and 13.3 percent stated they felt they were more productive. When asked how their libraries would compare their research productivity to their faculty colleagues, only 41.7 percent believed they would be viewed as similarly productive, while 25 percent felt they would be seen as less productive. A handful of respondents $(8.3 \%)$ stated they believed their libraries would evaluate them as more productive than their colleagues. Responses evince a relatively close match between respondents' self-assessments and their libraries' assessments of their productivity levels.

\section{Service}

Library faculty are often expected to engage in service activities, such as participation on library or university committees, involvement in professional associations, or participation in civic or community groups. Research on teaching faculty has shown that faculty of color often engage in high levels of service activities, despite the fact that service is often given less weight than research and publication when it comes to tenure or promotion. Such levels of service can make time management more challenging for faculty of color. To get a sense of the service commitments of library faculty of color, respondents indicated the amount of time they spent weekly on service, which is listed in table 6 . As the table shows, respondents spent a significant amount of time each week performing service activities, during regularly scheduled work time as well as during personal hours outside of work.

Committee work is a common form of service for faculty. Table 7 lists the types of committees on which the respondents had served. Most of the respondents $(85.0 \%)$ have served on a library committee, 70 percent served on a universitywide committee, and 68.3 percent served on a professional association committee. Leadership positions on committees are often evaluated more favorably in terms of service commitments. Respondents were asked about their service in leadership positions, typically as committee chair. The largest number of respondents (36.7\%) had not served as chair of a committee, while 26.7 percent had served as chair of only one committee. One issue to consider regarding committee work is the prestige afforded to certain committee appointments. At some institutions, committee assignments are rotated among the faculty to ensure even participation and to avoid excessive competition for coveted

\begin{tabular}{|c|c|c|}
\hline \multicolumn{3}{|c|}{$\begin{array}{c}\text { TABLE } 6 \\
\text { Time Spent on Service }(\mathrm{N}=60)\end{array}$} \\
\hline \multirow[b]{2}{*}{ No. of Hours Per Week } & \multicolumn{2}{|c|}{ No. (\%) of Respondents Performing Service Activities } \\
\hline & $\begin{array}{c}\text { During Scheduled Work } \\
\text { Time }\end{array}$ & $\begin{array}{l}\text { Outside of Scheduled } \\
\text { Work Time }\end{array}$ \\
\hline None & $6(10.0)$ & $16(26.7)$ \\
\hline $1-2$ & $26(43.3)$ & $24(40.0)$ \\
\hline $3-4$ & $14(23.3)$ & $14(23.3)$ \\
\hline $5-6$ & $8(13.3)$ & $2(3.3)$ \\
\hline More than six & $4(6.7)$ & $2(3.3)$ \\
\hline No response & $2(3.3)$ & $2(3.3)$ \\
\hline
\end{tabular}




\begin{tabular}{|c|c|}
\hline \multicolumn{2}{|c|}{$\begin{array}{c}\text { TABLE } 7 \\
\text { Committee Participation }(\mathrm{N}=60)\end{array}$} \\
\hline Type of Committee & $\begin{array}{l}\text { No. }(\%) \text { of Respondents } \\
\text { Serving on Committees }\end{array}$ \\
\hline Library committee & $51(85.0)$ \\
\hline Other departmental (nonlibrary) committee & $28(46.7)$ \\
\hline Universitywide committee & $42(70.0)$ \\
\hline Professional association committee & $41(68.3)$ \\
\hline Faculty search committee & $36(60.0)$ \\
\hline Other & $4(6.7)$ \\
\hline No committee participation & $2(3.3)$ \\
\hline No response & $1(1.7)$ \\
\hline
\end{tabular}

committee slots. Although 40 percent of respondents agreed that committee assignments were rotated fairly at their libraries, 25 percent stated committee assignments were not rotated to ensure fairness.

Faculty of color are often asked to serve on diversity-related committees even when such work might not be of interest to those faculty. In some cases, diversity committee work is undertaken in addition to other service activities, which can create an unbalanced workload. When asked to compare their service activity to library colleagues at their institutions, 43.3 percent of respondents thought they were more active than their colleagues. Thirty percent of respondents perceived themselves as similarly active to their colleagues, and 23.3 percent of respondents indicated they were less active than other library faculty. Respondents were then asked about their perceptions of their committee work in relation to their racial identity. A considerable number (55.0\%) of respondents stated they did not feel they were asked to serve on committees because of their race or ethnicity and 46.6 percent of respondents did not feel pressured into engaging in diversity-related service activities. These results seem to indicate that for roughly half of library faculty of color, race has little to do with committee appointments. This was contradicted, though, in a later part of the study, when respondents were asked to evaluate service expectations in relation to service expectations of White faculty librarians.

Despite the fact that the largest group of respondents stated they were more active than their colleagues in terms of service, the majority of respondents (55.0\%) felt they were fairly evaluated in terms of their service work. However, it is worth noting that 53.3 percent of respondents also indicated that they participated in service activities that were not formally acknowledged by their libraries. Library faculty of color are engaging in service activities that they value and that are time consuming, even though such activities are not equally valued by their colleagues. As one Native American respondent stated, "My commitment to my tribe is not understood by my colleagues, i.e. attending ceremonies or other activities ... I feel that they look down on this type of participation. A few have made belittling comments. Some colleagues totally disregard religious aspects of ceremonies or activities held at my village."

\section{Professional Development}

Many programs exist to help academic librarians develop the skills necessary to achieve tenure. To determine the prevalence and effectiveness of professional development programs at academic libraries for library faculty of color, 
respondents were asked two questions. Respondents were first asked about their perceptions of the importance of specific professional development programs, especially in terms of helping them achieve promotion or tenure. Their perceptions of importance can be found in table 8 . Respondents were then asked to rate how effective they felt those programs actually were at their institutions, if they had such programs in place. Generally speaking, an overwhelming majority of respondents $(80.0 \%)$ indicated they felt professional development programs were either very important or important in terms of their development and progress toward tenure and promotion, with funding for continuing education opportunities being cited most frequently.
Formal mentoring, informal mentoring, participation in peer support groups for untenured faculty, and participation in research and writing workshops were all closely rated behind funding. Funding for leadership opportunities geared toward racially underrepresented groups, such as participation in the ARL Leadership and Career Development Program (ARL LCDP) or MIECL, was seen as important by the smallest group of respondents. Overall, these responses underscore the need for academic libraries to implement specific programs to support tenure-track library faculty of color who may find themselves in academic positions with little experience or preparation for participation in a scholarly community. ${ }^{23}$

\begin{tabular}{|c|c|c|c|c|c|}
\hline Perceptions of the Imp & ortance of & $\begin{array}{l}\text { TABLE } 8 \\
\text { Profession }\end{array}$ & al Developm & ent Program & $(N=60)$ \\
\hline & & & (\%) of Respon & lents & \\
\hline Type of Program & $\begin{array}{c}\text { Very } \\
\text { Important }\end{array}$ & Important & Unimportant & $\begin{array}{c}\text { Very } \\
\text { Unimportant }\end{array}$ & $\begin{array}{c}\text { No } \\
\text { Response }\end{array}$ \\
\hline $\begin{array}{l}\text { Formal mentoring pro- } \\
\text { gram for junior faculty }\end{array}$ & $25(41.7)$ & $29(48.3)$ & $3(5.0)$ & $1(1.7)$ & $2(3.3)$ \\
\hline Informal mentoring & $38(63.3)$ & $15(25.0)$ & $1(1.7)$ & $1(1.7)$ & $5(8.3)$ \\
\hline $\begin{array}{l}\text { Funding for continuing } \\
\text { education opportunities, } \\
\text { such as workshops and } \\
\text { conferences }\end{array}$ & $44(73.3)$ & $13(21.7)$ & $1(1.7)$ & $0(0.0)$ & $2(3.3)$ \\
\hline $\begin{array}{l}\text { Funding for leadership } \\
\text { opportunities, such as } \\
\text { the ARL Leadership and } \\
\text { Career Development } \\
\text { program, or the Min- } \\
\text { nesota Institute for Early } \\
\text { Career Librarians from } \\
\text { Traditionally Underrepre- } \\
\text { sented Groups }\end{array}$ & $30(50.0)$ & $18(30.0)$ & $5(8.3)$ & $3(5.0)$ & $4(6.7)$ \\
\hline $\begin{array}{l}\text { Participation in peer sup- } \\
\text { port groups for untenured } \\
\text { librarians }\end{array}$ & $26(43.3)$ & $25(41.7)$ & $6(10.0)$ & $0(0.0)$ & $3(5.0)$ \\
\hline $\begin{array}{l}\text { Workshops for junior } \\
\text { faculty about how to } \\
\text { conduct research meth- } \\
\text { ods and how to write for } \\
\text { publication }\end{array}$ & $29(48.3)$ & $21(35.0)$ & $7(11.7)$ & $1(1.7)$ & $2(3.3)$ \\
\hline
\end{tabular}


Tenure and Promotion Experiences of Academic Librarians of Color 293

\section{TABLE 9}

\section{Perceptions of the Effectiveness of Professional Development Programs ( $=60)$}

\begin{tabular}{|c|c|c|c|c|c|c|}
\hline \multirow[b]{2}{*}{ Type of Program } & \multicolumn{6}{|c|}{ No. (\%) of Respondents } \\
\hline & $\begin{array}{c}\text { Not } \\
\text { Applicable }\end{array}$ & $\begin{array}{c}\text { Very } \\
\text { Effective }\end{array}$ & Effective & Ineffective & $\begin{array}{c}\text { Very } \\
\text { Ineffective }\end{array}$ & $\begin{array}{c}\text { No } \\
\text { Response }\end{array}$ \\
\hline $\begin{array}{l}\text { Formal mentoring } \\
\text { program for junior } \\
\text { faculty }\end{array}$ & $22(36.7)$ & $6(10.0)$ & $12(20.0)$ & $9(15.0)$ & $8(13.3)$ & $3(5.0)$ \\
\hline Informal mentoring & $10(16.7)$ & $18(30.0)$ & $16(26.7)$ & $6(10.0)$ & $7(11.7)$ & $3(5.0)$ \\
\hline $\begin{array}{l}\text { Funding for con- } \\
\text { tinuing education } \\
\text { opportunities, such } \\
\text { as workshops and } \\
\text { conferences }\end{array}$ & $8(13.3)$ & $11(18.3)$ & $29(48.3)$ & $8(13.3)$ & $2(3.3)$ & $2(3.3)$ \\
\hline $\begin{array}{l}\text { Funding for leader- } \\
\text { ship opportunities, } \\
\text { such as the ARL } \\
\text { Leadership and } \\
\text { Career Develop- } \\
\text { ment program, or the } \\
\text { Minnesota Institute } \\
\text { for Early Career } \\
\text { Librarians from } \\
\text { Traditionally Under- } \\
\text { represented Groups }\end{array}$ & $18(30.0)$ & $8(13.3)$ & $16(26.7)$ & $12(20.0)$ & $4(6.7)$ & $2(3.3)$ \\
\hline $\begin{array}{l}\text { Participation in peer } \\
\text { support groups for } \\
\text { untenured librarians }\end{array}$ & $16(26.7)$ & $4(6.7)$ & $18(30.0)$ & $11(18.3)$ & $7(11.7)$ & $4(6.7)$ \\
\hline $\begin{array}{l}\text { Workshops for } \\
\text { junior faculty about } \\
\text { how to conduct } \\
\text { research methods } \\
\text { and how to write for } \\
\text { publication }\end{array}$ & $20(33.3)$ & $5(8.3)$ & $13(21.7)$ & $12(20.0)$ & $7(11.7)$ & $2(3.3)$ \\
\hline
\end{tabular}

Respondents were asked to rate the actual effectiveness of existing professional development programs, regardless of how important they felt those programs were. A summary of the ratings of effectiveness can be found in table 9. Informal mentoring was cited by the highest number of respondents $(56.7 \%)$ as an effective form of professional development. Only 30 percent rated formal mentoring as effective, and a nearly equivalent number of respondents $(28.3 \%)$ rated it as an ineffective form of development. One explanation for the difference between perceptions of informal and formal mentoring could be the very nature of the relationship between the mentee and mentor. Informal mentoring situations may arise when two individuals find they have a positive working relationship that is built upon mutual interests or compatible personality types. Formal mentoring situations may backfire if a mentor and mentee are involuntarily paired and fail to develop a good working relationship. Peer support groups were cited as an effective form of development by 36.7 percent of respondents, while 30 percent 
felt such groups were not effective. The level of success for such groups may depend heavily upon individual relationships within the group, as well as overall group dynamics.

External opportunities for professional development are readily available to librarians, although not always easily accessible. Funding for continuing education opportunities, such as attendance at conferences and workshops, was rated as an effective form of professional development by a large number of respondents $(66.7 \%)$. Funding for participation in leadership development programs, such as the ARL LCDP, was rated as effective by 40 percent of respondents, while 26.7 percent rated funding for these programs as ineffective. One possible explanation for the disparity between the perceived value of leadership programs and their actual effectiveness might be the fact that these programs are often highly selective. Since only a tiny fraction of librarians of color are eligible to participate, such programs might not be seen as a useful or readily available form of professional development.

One surprising finding from the survey was that nearly equivalent numbers of respondents rated workshops meant to assist with research methods and writing for publication as both effective $(30.0 \%)$ and ineffective $(31.7 \%)$. Given the relative weight with which research and publication is evaluated, we expected respondents to rate those workshops as not only important, but useful. Further research would have to be conducted to explore why such programs are not seen as effective as they should be. There seems to be a large disparity between how library faculty of color value professional development programs and their perceptions of the actual effectiveness of those programs.

\section{Obstacles to Earning Tenure or Promotion}

Respondents were asked to state perceived obstacles or challenges to earning tenure or promotion, as well as to provide commentary about their experiences overall with the tenure and promotion process. Roughly half of the respondents provided responses to both questions. Several recurring topics appeared throughout the responses: the challenges of conducting research and writing for publication, the need for mentoring and peer support, and the role of race within the framework of tenure.

Although issues regarding time management, mentoring, and peer support are certainly not limited to the experiences of library faculty of color, racial climate and perceptions of race are factors that interweave with these issues to complicate the experiences of library faculty of color. For example, one respondent demonstrated how a cycle of institutionalized inequity can be perpetuated within an academic library environment:

In my library I'm viewed and treated as a second class citizen. My skills, knowledge and abilities are not valued in their own right. They are treated as commodities to be used to serve others. I [am] treated as just the "hired help". I'm not given the opportunity or support that my white counterparts are given. For example I've been bounced around from work area to work area never being given the time to focus in an area long enough or in-depth enough to get to the point of engaging in scholarship. In contrast my white counterpoints are able to focus on an area long enough to get to the point of engaging in scholarship. When it comes time for evaluation I'm then evaluated as less productive because I have written fewer articles. Evaluators can then claim they are being fair and objective because they are evaluating candidates by the same criteria-how many articles the candidate has written. It's a form of subtle discrimination that has become institutionalized. 
Another respondent pointed out the lack of mentoring and constructive feedback from senior faculty as a serious impediment to successful publishing:

Publish, publish, publish without informal coaching, networking, or constructive feedback. Also an obstacle is counterproductive criticism without remedy or suggestions from [sic] improvement from those in a position to provide junior library faculty the most valuable help. Of course, there are those (especially white) senior members who have eagerly helped white, junior counterparts by providing them co-authorship opportunities. This is a concrete, tangible way to be taken under one's wing. Others (especially non-white faculty) have been offered the customary abstract opportunities through workshops, presentations, and the like, but the senior white faculty stop short of actually allowing non-whites the opportunity to learn through leadership such as this.

In some instances, the respondents expressed difficulties with how their research was viewed by their peers, echoing findings in the literature. As one person stated, "My research was originally look [sic] down on as a poor choice for possibly getting tenured. However, my research on a specific issue of people of color was innovative and new. This I believe helped me... along with good reviewers in my field of research. If I had listen [sic] to these informal comments, I would have left nontenured." Another librarian expressed similar problems: "I'm also struggling to obtain funding. A project on mentoring librarians of color was rejected, and I suspect that my project was unfairly evaluated. Another research project on the features of the ... catalog was accepted instead of my project. I thought my project had more social weight and professional significance."
Respondents were able to provide more nuanced explanations of the benefits and drawbacks of mentoring in the free-text part of the survey. Most respondents stated the value of mentors guiding them through the tenure process. As one person remarked, "I feel that mentoring has played a vital role in my success in my current position; I have a supervisor who provides guidance and is great at evaluating the impact an opportunity may have on my ability to balance work and home life." Several respondents who recognized the challenges of trying to earn tenure mentioned serving as a mentor to others, as one respondent put it, "...to make someone else's journey a bit easier." However, some respondents had a less than favorable view of mentoring. Some indicated the success of a mentoring program depended upon the relationship between the mentor and mentee, and whether the mentor voluntarily entered that mentoring relationship or was assigned to that mentee. One respondent offered a different perspective on the idea of mentoring within the larger framework of professional development for librarians of color:

Mentoring programs and institutes targeted at librarians of color are not the answer. I believe they are making the situation in academic libraries worse. These programs imply that the problem is with the librarians of color, that librarians of color need to be taught to assimilate. The real problem is institutionalized racism in academic libraries. Instead of sending me to a program/institute, administrators...need to be sent to programs to raise their awareness about how their attitudes and behaviors are forms of discrimination and create barriers for librarians of color who are trying to obtain tenure and/or promotion.

However, formal mentoring programs are not the only types of professional development available to librarians of 
color. Several respondents discussed the importance and need for more informal mentoring relationships and peer support networks as a means for alleviating feelings of isolation, particularly in environments where they found themselves a racial minority (which was the case for most respondents).

Explicit comments about race and its role in the tenure and promotion process were mixed. Several respondents felt race was not an obstacle, as summarized by one comment: “I don't think my race or ethnicity was a barrier to my application for promotion and tenure." Another respondent felt the difficulties in earning tenure or promotion were experienced by most librarians, regardless of race: "Tenure is difficult to achieve for all librarians at my institution. I did not feel I was treated unfairly or differently from the others." Some respondents also mentioned the challenges of navigating contentious relationships with supervisors, which could also impede the tenure or promotion process. Unless pointed out by the respondents as an explicit factor in those relationships, it is unclear how much perceptions of race or racist beliefs affected the supervisors' abilities to interact well with those librarians. Based upon respondents' comments, lack of representation, particularly at higher levels of administration, continues to be an issue for librarians of color, which can hinder an institution's ability to improve its overall levels of cultural competence and racial climate. While a focus on recruitment and retention remains important, more needs to be done in terms of advancement and development. As one librarian stated (in reference to important informal social networks at their institution): "I believe the lack of current faculty of color overall adds to the problem of gaining ground in terms of library faculty of color, and I also believe that academia does not necessarily promote the same networks to faculty of color at any level-either in or out of the library."

\section{Organizational Climate and Culture}

Research has shown that teaching faculty of color have experienced working in hostile or "chilly" work environments, exacerbated by feelings of isolation and lack of support from colleagues. ${ }^{24}$ Survey respondents were asked to provide their perceptions of their interactions with colleagues and their work environments to determine if library faculty of color face similar issues. Although none of the respondents had previously listed collegiality as a specific criterion for evaluation, cooperative and collaborative interactions among faculty members is often seen as an important component of academic culture.

Respondents were asked to share their perceptions of their interactions with fellow faculty librarians, including supervisors. The majority of respondents $(66.7 \%)$ felt they were fairly evaluated by their immediate supervisors. Nearly half of the respondents $(48.4 \%)$ indicated they were able to fully participate in decisionmaking and problem-solving processes at their libraries. However, 31.7 percent of respondents disagreed with this statement. The same number of respondents also felt they could not freely voice their opinions at their library, although 53.3 percent indicated they could. Forty percent indicated feelings of isolation, while a slightly higher number $(43.4 \%)$ stated they did not feel isolated. One third of respondents felt excluded from informal networks at their libraries, but a slightly higher number (41.7\%) stated they did not feel left out. A majority (61.6\%) felt they were respected by their colleagues, and the same number of respondents indicated their colleagues sought their opinions on work-related matters. Surprisingly, a significantly smaller number of respondents $(31.7 \%)$ felt their colleagues valued their research; 21.7 percent of respondents felt their research was not valued, while the majority of respondents $(43.4 \%)$ did not have an opinion on the matter. Only 38.4 percent of the respondents stated their colleagues showed an interest in 


\begin{tabular}{|c|c|c|c|c|c|c|}
\hline \multicolumn{7}{|c|}{$\begin{array}{c}\text { TABLE } 10 \\
\text { Perceptions of Workplace Climate }(\mathrm{N}=60)\end{array}$} \\
\hline \multirow[b]{2}{*}{$\begin{array}{c}\text { Statements about Workplace } \\
\text { Climate }\end{array}$} & \multicolumn{6}{|c|}{ No. (\%) of Respondents } \\
\hline & $\begin{array}{c}\text { Strongly } \\
\text { Agree }\end{array}$ & Agree & $\begin{array}{l}\text { Neither } \\
\text { Agree nor } \\
\text { Disagree }\end{array}$ & Disagree & $\begin{array}{l}\text { Strongly } \\
\text { Disagree }\end{array}$ & $\begin{array}{c}\text { No } \\
\text { Response }\end{array}$ \\
\hline $\begin{array}{l}\text { Library faculty are seri- } \\
\text { ous about treating library } \\
\text { faculty of color and white } \\
\text { library faculty equally. }\end{array}$ & $9(15.0)$ & $\begin{array}{c}16 \\
(26.7)\end{array}$ & $13(21.7)$ & $\begin{array}{c}13 \\
(21.7)\end{array}$ & $7(11.7)$ & $2(3.3)$ \\
\hline $\begin{array}{l}\text { Library faculty of color are } \\
\text { less likely than their white } \\
\text { counterparts to have influ- } \\
\text { ence in library politics and } \\
\text { administration. }\end{array}$ & 7 (11.7) & $\begin{array}{c}13 \\
(21.7)\end{array}$ & $14(23.3)$ & $\begin{array}{c}15 \\
(25.0)\end{array}$ & $9(15.0)$ & $2(3.3)$ \\
\hline $\begin{array}{l}\text { Library faculty of color } \\
\text { are more likely to receive } \\
\text { feedback about their per- } \\
\text { formance than white library } \\
\text { faculty do. }\end{array}$ & $1(1.7)$ & $\begin{array}{c}7 \\
(11.7)\end{array}$ & $24(40.0)$ & $\begin{array}{c}18 \\
(30.0)\end{array}$ & $8(13.3)$ & $2(3.3)$ \\
\hline $\begin{array}{l}\text { Discrimination against } \\
\text { or harassment of library } \\
\text { faculty of color is a problem } \\
\text { at my library. }\end{array}$ & $4(6.7)$ & $\begin{array}{c}6 \\
(10.0)\end{array}$ & $16(26.7)$ & $\begin{array}{c}16 \\
(26.7)\end{array}$ & $\begin{array}{c}15 \\
(25.0)\end{array}$ & $3(5.0)$ \\
\hline $\begin{array}{l}\text { White library faculty are } \\
\text { more likely than library fac- } \\
\text { ulty of color to be involved } \\
\text { in informal social networks } \\
\text { within the library. }\end{array}$ & $\begin{array}{c}10 \\
(16.7)\end{array}$ & $\begin{array}{c}9 \\
(15.0)\end{array}$ & $17(28.3)$ & $\begin{array}{c}11 \\
(18.3)\end{array}$ & $\begin{array}{c}10 \\
(16.7)\end{array}$ & $3(5.0)$ \\
\hline $\begin{array}{l}\text { Library faculty of color } \\
\text { are more likely to be asked } \\
\text { to participate in diversity } \\
\text { initiatives in the library } \\
\text { (such as library diversity } \\
\text { committees) than white } \\
\text { library faculty. }\end{array}$ & $9(15.0)$ & $\begin{array}{c}16 \\
(26.7)\end{array}$ & $16(26.7)$ & 7 (11.7) & $9(15.0)$ & $3(5.0)$ \\
\hline $\begin{array}{l}\text { Library faculty of color are } \\
\text { more likely to be asked to } \\
\text { serve as a liaison to campus } \\
\text { units that traditionally serve } \\
\text { diverse populations (campus } \\
\text { diversity committee, Office } \\
\text { for Multicultural Student } \\
\text { Affairs, Black Cultural Cen- } \\
\text { ter, etc.) than white library } \\
\text { faculty. }\end{array}$ & $9(15.0)$ & $\begin{array}{c}24 \\
(40.0)\end{array}$ & $15(25.0)$ & $7(11.7)$ & $3(5.0)$ & $2(3.3)$ \\
\hline
\end{tabular}


their professional development. Despite this general lack of interest in their research or professional development, 43.4 percent of respondents indicated adequate opportunities for collaboration with senior colleagues. Collegiality is a key component of a faculty member's professional worklife, and having the opportunity to work with senior colleagues can greatly enhance it. Furthermore, collaborations between senior and junior faculty on specific tasks can lead to an informal mentoring relationship that helps the junior faculty member develop professionally.

Research has shown that, for teaching faculty of color, working in a negative racial climate can negatively impact both job satisfaction and overall retention rates, especially for Black or African American and Hispanic or Latino faculty. ${ }^{25}$ Respondents were asked about their perceptions of the racial climate of their work environments; responses are provided in table 10.

Slightly more than half of the respondents indicated racial discrimination or harassment was not a problem at work. Only 16.7 percent of respondents felt it was a problem at work, while a notable number of respondents $(26.7 \%)$ had no opinion on the issue. Although 41.7 percent of respondents indicated library faculty at their institution were serious about treating faculty equally regardless of race, 33.3 percent disagreed with this statement, and a considerable number $(21.7 \%)$ offered no opinion on the matter.

Explicit discrimination is not always the leading cause of negative racial climates; "racial hierarchy and advantage can be perpetuated without malicious intent." ${ }^{26}$ Respondents shared their perceptions about less explicit factors that can shape the racial climate of their workplaces, and the results were very mixed. Forty percent stated White faculty were no more likely to have influence in library politics or administration than library faculty of color, but 33.4 percent felt White faculty were more influential. Respondents were almost equally split regarding the issue of White library faculty and informal networks; 31.7 percent stated White faculty were more likely to be involved in such networks, 26.7 percent felt White faculty were not, and 28.3 percent offered no opinion on the issue. However, when asked about service commitments, 41.7 percent of respondents felt library faculty of color were more likely to be asked to serve on library diversity initiatives than White faculty. Fifty-five percent felt library faculty of color were more likely to be asked to serve as a liaison to diversity groups or units outside the library, such as campus diversity committees or multicultural student services. As one respondent stated, "I was seen as a diversity hire and appointed to the diversity committee almost immediately. The assumption was that my interests, research and otherwise, were diversity despite having a technical history." Such assumptions can lead to hidden workloads for library faculty of color, making it more difficult to manage their time and maintain balance. Library faculty of color are often expected to spend time on diversity activities while their White colleagues are not burdened by the same expectations and therefore free to devote time to more prestigious committees or to research and publication activities.

\section{Job Satisfaction and Retention}

After reflecting upon their work as library faculty, respondents were asked about their levels of job satisfaction. A majority of the respondents $(61.7 \%)$ were satisfied with library expectations of their overall work performance. Slightly less (56.7\%) were satisfied with the amount of time they spent on regular work duties. Roughly equivalent numbers of respondents were satisfied with library expectations of their scholarly activities (40.0\%) and their service activities (43.3\%). However, fewer numbers were satisfied with the amount of time they actually spent on those activities; only 26.7 percent were satisfied with the amount of time they spent on research, and 40 percent were satisfied 
with the amount of time they spent on service. Fifty-five percent were satisfied with their overall levels of productivity. These findings reiterate the challenges of managing a very full workload.

The majority of respondents $(61.6 \%)$ were satisfied with their libraries as a place to work. In terms of their overall career progression, 56.7 percent stated they were satisfied with how their professional lives have developed over the years. However, satisfaction levels may not be enough to persuade or dissuade a faculty member from leaving an institution and seeking employment elsewhere. Respondents were asked directly about what they thought their plans would be regarding length of employment with their current institutions. Assuming they would achieve tenure, tenure-track librarians of color were asked how long they would stay at their current institutions. Out of those respondents, 28 percent stated they planned to remain at their current place of employment for the duration of their careers. Only 12.5 percent stated they would remain for the next five years, while a surprising 25 percent stated they would seek employment elsewhere as soon as possible. A significant number of tenure-track librarians (34.3\%) had not given any thought to their plans beyond earning tenure. Tenured librarians, including those still eligible for promotions, responded to a similar question about their employment plans. Forty percent of those respondents planned to remain for the duration of their careers at their current libraries. An equal number stated they did not know how long they planned to stay. A small number of tenured respondents $(16.0 \%)$ planned to remain for at least the next five years. Only one respondent stated s/he planned to leave as soon as possible.

The responses from both tenure-track and tenured librarians of color were relatively mixed in terms of employment plans. When examined within the context of previous responses concerning job responsibilities, perceived expectations, and work climate, it comes as no surprise that definitive relationships among all those factors and the decision to stay with current employers or to seek employment elsewhere are difficult to state with certainty. However, both tenured and tenure-track respondents demonstrated significant degrees of uncertainty when stating employment plans with their current institutions. A notable number of tenure-track respondents indicated a desire to move on to another institution even if they successfully earned tenure. Why would these librarians choose to work elsewhere if they achieve tenure, when the tenure process is so lengthy and arduous? Although this survey did address retention by asking about respondents' plans for staying with their current employers, it did not examine whether any academic librarians of color, tenured or tenure-track, planned to leave the profession completely after undergoing a tenure or promotion review.

\section{Recommendations}

The original purpose of this study was to gain insight into the experiences of library faculty of color as they move through the tenure and promotion process. The responses begin to shed some light upon the challenges these librarians face as they work toward their professional goals. Workload issues make the process of conducting research and writing for publication very difficult. Many struggle with service commitments, particularly when they are called upon to provide the "diversity" perspective within their institutions. Some have had to contend with both implicit and explicit racism throughout their professional lives. We found that the results of this survey highlight the abilities of library faculty of color to endure and overcome difficult circumstances.

Based upon the results and narrative responses from the survey, there are several issues that should be evaluated at academic libraries to ensure more positive experiences for library faculty of color. 
Academic library administrators and tenure committees should manage the tenure and promotion process in ways that ensure equitable tenure-track experiences for librarians of color. Institutions must conduct periodic assessments of their policies and processes to maintain clear objectives and transparent practices. Libraries looking to implement programs such as mentoring or peer support groups that are designed to help junior faculty should engage in regular assessment to ensure such programs are actually effective. Supporting and coordinating such initiatives with strained budgets may be a challenge. However, ensuring that library faculty of color develop successful grantwriting skills can benefit both the library as well as the individual faculty member, leading to increased funding for the library and a well-rounded tenure portfolio for the individual. Library administrators should also emphasize the value of the work of library faculty of color who engage with and provide service to communities of color served by their institutions. The solution for integrating this work into a tenure and promotion agenda is two-fold. Library faculty of color must find ways to demonstrate the value of such work within an academic context, and library administrators must actively appraise and promote diversity research, service, and programming within the larger organizational culture.

\section{Conclusion}

As researchers working from a critical race theory standpoint, we wanted to give voice specifically to racially and ethnically underrepresented librarians who otherwise might not have safe venues to share their opinions. The narrative commentary provided by respondents was particularly informative, underscoring the need for further qualitative research. We recognize that, to better understand how systemic racial inequities might be embedded within academic libraries, a larger survey sample must be obtained that disaggregates the responses of librarians of color into specific racial and ethnic categories and also includes the experiences of White academic librarians. For example, while African American librarians may have some shared experiences that are built upon others' perceptions of their racial identities, those experiences may differ from those of Asian American librarians, who must contend with different constructions of race. Future research should also explore other dimensions of difference, such as gender or ability, as these factors often intersect in complex ways with race and ethnicity that could have a significant impact upon tenure and promotion experiences for academic librarians. Despite these caveats, the results are useful to consider as librarians, administrators, and other faculty examine institutional policies and practices to recruit and retain librarians of color. The need for future research should not preclude library decision-makers from using these results to begin assessing the tenure policies, practices, and overall climate of their own institutions to ensure greater equity for all library faculty.

\section{Notes}

1. Allison M. Sutton, "Bridging the Gap in Early Library Education for African Americans: The Negro Teacher-Librarian Training Program (1936-1939)," The Journal of Negro Education 74, no. 2 (2005): $138-50$.

2. American Library Association, "Diversity Counts Report," available online at www.ala.org/ala/ aboutala/offices/diversity/diversitycounts/diversitycounts_rev0.pdf [accessed 30 August 2009].

3. Association of College \& Research Libraries, "A Guideline for the Appointment, Promotion, and Tenure of Academic Librarians: Approved at ALA Annual Conference, June 2005," College $\mathcal{E}$ Research Libraries News 66, no. 9 (Oct. 2005): 668-76.

4. Betsy Park and Robert Riggs, "Tenure and Promotion: A Study of Practices by Institutional Type," Journal of Academic Librarianship 19, no. 2 (May 1993): 72-77; Betsy Park and Robert Riggs, 


\section{Tenure and Promotion Experiences of Academic Librarians of Color 301}

"Status of the Profession: A 1989 National Survey of Tenure and Promotion Policies for Academic Librarians," College \& Research Libraries 52, no. 3 (May 1991): 275-89.

5. Linda R. Musser, "Effective Retention Strategies for Diverse Employees," Journal of Library Administration 33, no. 1/2 (2001): 63-72.

6. Deborah Lee, "On the Tenure Track: Strategies for Success," College \& Research Libraries News 68, no. 10 (Nov. 2007): 626-30; Todd Spires, "The Busy Librarian: Prioritizing Tenure and Dealing with Stress for Academic Library Professionals," Illinois Libraries 86, no. 4 (2007): 101-08.

7. Jeannie P. Miller and Candace R. Benefiel, "Academic Librarians and the Pursuit of Tenure: The Support Group as a Strategy for Success," College \& Research Libraries 59, no. 3 (May 1998): 260-65; Dana Keyse, Elizabeth W. Kraemer, and Julie Voelck, "Mentoring Untenured Librarians: All It Takes Is a Little Un-TLC," College \& Research Libraries News 64, no. 6 (June 2003): 378-80.

8. Peggy Johnson, "Retaining and Advancing Librarians of Color," College \& Research Libraries 68, no. 5 (Sept. 2007): 405-17; Eric Kofi Acree, Sharon K. Epps, Yolanda Gilmore, and Charmaine Henriques, "Using Professional Development as a Retention Tool for Underrepresented Academic Librarians," Journal of Library Administration 33, no. 1/2 (2001): 45-61.

9. Camila A. Alire, "The New Beginnings Program: A Retention Program for Junior Faculty of Color," Journal of Library Administration 33, no.1/2 (2001): 21-30.

10. Jan S. Squire, "Job Satisfaction and the Ethnic Minority Librarian," Library Administration E Management 5, no. 4 (1991): 194-203.

11. Joyce K. Thornton, "Job Satisfaction of Librarians of African Descent Employed in ARL Academic Libraries," College E Research Libraries 61, no. 3 (May 2000): 217-32.

12. Deborah B. Henry and Tina M. Neville, "Research, Publication, and Service Patterns of Florida Academic Librarians," The Journal of Academic Librarianship 30, no. 6 (Nov. 2004): 435-51; David Fox, "The Scholarship of Canadian Research University Librarians," Partnership: The Canadian Journal of Library \& Information Practice \& Research 2, no. 2 (2007): 1-25.

13. W. Bede Mitchell and Mary Reichel, "Publish or Perish: A Dilemma for Academic Librarians?" College \& Research Libraries 60, no. 3 (May 1999): 232-43.

14. Joseph Fennewald, "Research Productivity among Librarians: Factors Leading to Publications at Penn State," College \& Research Libraries 69, no. 2 (Mar. 2008): 104-16.

15. Richard Sapon-White, Valery King, and Anne Christie, "Supporting a Culture of Scholarship for Academic Librarians," Portal: Libraries and the Academy 4, no. 3 (July 2004): 407-22.

16. Berta Vigil Laden and Linda Serra Hagedorn, "Job Satisfaction among Faculty of Color in Academe: Individual Survivors or Institutional Transformers?" New Directions for Institutional Research 27, no. 1 (2000): 57-66; Uma M. Jayakumar, Tyrone C. Howard, Walter A. Allen, and June C. Han, "Racial Privilege in the Professoriate: An Exploration of Campus Climate, Retention, and Satisfaction," Journal of Higher Education 80, no. 5 (Sept./Oct. 2009): 538-63.

17. Adalberto Aguirre, Jr., Women and Minority Faculty in the Academic Workplace: Recruitment, Retention, and Academic Culture (San Francisco: Jossey-Bass, 2000); Laden and Hagedorn, "Job Satisfaction"; Alvin Evans and Edna Breinig Chun, Are the Walls Really Down? Behavioral and Organizational Barriers to Faculty and Staff Diversity (San Francisco: Jossey-Bass, 2007).

18. Aguirre, Women and Minority Faculty, 39.

19. Edward Taylor, "A Primer on Critical Race Theory: Who Are the Critical Race Theorists and What Are They Saying?" Journal of Blacks in Higher Education, no. 19 (1998): 122.

20. Christine A. Stanley, "Coloring the Academic Landscape: Faculty of Color Breaking the Silence in Predominantly White Colleges and Universities," American Educational Research Journal 43, no. 4 (2006): 701-36.

21. Mitchell and Reichel, "Publish or Perish," 233.

22. Paula De Simone Watson. "Publication Activity among Academic Librarians," College $\mathcal{E}$ Research Libraries 38, no. 5 (Sept. 1997): 375-84.

23. Sapon-White, King, and Christie, "Supporting a Culture of Scholarship," 407.

24. Jayakumar, Howard, Allen, and Han, "Racial Privilege in the Professoriate," 533.

25. Ibid, 555.

26. Ibid, 555 . 